\title{
The Effect of Earnings Quality on the Returns-Earnings Relationship: Evidence from Jordan
}

\author{
Alaa’ A. Abdelkarim ${ }^{1} \&$ Mamoun M. Al-Debi’e ${ }^{1}$ \\ ${ }^{1}$ School of Business, The University of Jordan, Amman, Jordan \\ Correspondence: Mamoun M. Al-Debi'e, School of Business, The University of Jordan, Amman, Jordan. Tel: \\ 962-7-8054-4445; Fax: 962-6-530-0801
}

Received: October 19, 2015

Accepted: November 8, 2015

Online Published: November 12, 2015

doi:10.5430/afr.v4n4p165

URL: http://dx.doi.org/10.5430/afr.v4n4p165

\begin{abstract}
This study examines the returns-earnings relationship taking into consideration the quality of earnings for a sample of industrial and service Jordanian companies listed on Amman Stock Exchange over the period (2002-2012). The study uses five simple and direct measures (indicators) of earnings quality that could be used by any financial statement user. Using Ordinary Least-Squares Regression (OLS), the results show that the returns-earnings relationship has improved after sorting data based on the quality of earnings. Moreover, after adding the age of companies as a control variable results have generally improved except for some indicators. At last, earnings quality sorting was used for industrial sector companies and service sector companies each separately. The results show that returns-earnings relationship is stronger for service sector companies than for industrial sector companies in general.
\end{abstract}

Keywords: Earnings quality, Earnings per share, Stock market return, Earnings response coefficient, Operating cash flow, Net income, Operating income, Non-operating income

\section{Introduction}

This study seeks to improve the returns-earnings relationship using five simple indicators as proxies for measuring earnings quality (cash flow to accruals, cash flow to operating income, the stability of earnings, the trend of earnings, and the source of earnings).

Several studies have investigated the returns-earnings relationship under different assumptions. At first, (king, 1966) illustrated that stock prices and market and industry returns characterize a similar behavior. Secondly, (Ball \& Brown, 1968) inferred a positive relationship between stock returns and earnings in their study of accounting income numbers. (Lev, 1989) reviewed two decades of accounting studies concluding that changes in earnings interpret changes in stock returns only by $10-15 \%$.

Researcher have tried to examine the reasons behind the weak returns-earnings relationship using different methodologies; (Easton \& Harris, 1991) and (Al-Debi'e \& Abu Nassar, 1999) used two proxies for unexpected earnings , the "level of earnings" and the "changes of earnings". (Easton, Harris, \& Ohlson, 1992), (Shroff, 2002), (Abdelqader, Al-Debi'e, \& Gharaibeh, 2008) expanded the measurement window claiming that the returns-earnings relationship is not contemporaneous. Other researchers worked on improving the returns-earnings relationship by studying the quality of earnings. (Dechow, Weili, \& Schrand, 2010) clarified that the definition of earnings quality must be linked to "a specific decision" otherwise it will be meaningless.

Researchers evaluated the quality of earnings based on different measures such as; changes in accounting principles or estimates (Penman \& Zhang, 1999), accounting accruals (K. Chan, L. Chan, Jegadeesh, \& Lakonishok, 2004), the persistence of earnings (Richardson, Sloan, Soliman, \& Tuna, 2005), the allocation of accruals and cash flows (Dechow \& Dichev, 2002), earnings fixation (Houge \& Loughran, 2000), etc.

The following sections present previous literature on the improvements in the study of the returns-earnings relationship and earnings quality followed by the study methodology which includes the study variables, model, sample and descriptive statistics. Then the study results are presented followed by a conclusion of the study.

\section{Literature Review}

Using "earnings level" and "changes in earnings" as explanatory variables to enhance the study of the returns-earnings relationship, (Al-Debi'e \& Abu Nassar, 1999) illustrated that both variables are proper explanatory variables to explain the changes in stocks prices clarifying that "earnings level" variable explains the changes in 
stock returns better than "changes in earnings" variable. The same was inferred previously by (Easton \& Harris, 1991); they explained that "level of earnings" variable has more information content than "changes of earnings" variable.

(Abdelqader et al., 2008) studied the effect of expanding the measurement window on the returns-earnings relationship. They found that a longer measurement window causes an increase in the strength of the returns-earnings relationship and in the earnings response coefficient.

One of the major improvements used in studying the returns-earnings relationship is evaluating the quality of earnings. (Lev, 1989) explained that earnings quality is not considered while studying the returns-earnings relationship. (Abdelghany, 2005) illustrated that there is no agreement on one measure or technique in assessing the quality of earnings for companies. He suggested that several measures of earnings quality should be applied in order to assess whether earnings are of a high-quality or not which results in relevant and reliable information for investors. Researchers presented different definitions of earnings quality; each researcher defined it based on the context of his/her study. (Richardson, Sloan, Soliman, \& Tuna, 2001) proclaimed that earnings quality is represented by earnings persistence i.e. the company's ability to carry its performance to the next year.

(Hodge, 2003) revealed that the difference between reported earnings and actual "unbiased and accurate" earnings identifies the quality of earnings. The same definition was proposed previously by (Pratt, 2000) who suggested that the quality of earnings is affected by the "unreported events" which companies do not account for in their financial statements such as human values in services companies, formulas and patents in the high-tech industry, etc. On the other hand, (Mikhail, Walther, \& Willis, 2003) examined the association of earnings and cash flows in their definition of earnings quality. They concluded that when past earnings are reflected in future cash flows, the quality of earnings is considered to be high.

(Kirschenheiter \& Melumad, 2004) discussed that earnings quality increases by the extent to which reported earnings reflect the company's value in the long term. (White, Sondhi, \& Fried, 2003) clarified that earnings quality is measured by conservatism degree of earnings. He explained that using accounting estimates and methods that do not tend to magnify earnings represents conservatism. Conservative earnings are considered to be "high-quality" earnings as the reported earnings will be free from overstatements. (Revsine, Collins, \& Johnson, 1999) presented that the sustainability of earnings over time differentiates between the high and low-quality of earnings.

(Dechow et al., 2010) focused on the importance of linking earnings quality to the decision usefulness i.e. to the study context, in order to have a better interpretation of any study of earnings quality. Moreover, they used proxies of earnings quality in their study such as persistence \& accruals, smoothness, timeliness, accounting methods, etc. They found that there is no superior proxy among the tested proxies that could be used as a standard measure of earnings quality. (Chan et al., 2004) discussed earnings quality effect on stock returns, going in their research beyond the bottom-line income. They focused on the importance of other items in the financial statements and how substantial they could be in predicting future stock returns. Several studies examined the informativeness of earnings components whether separately or together. (Bernstein, 1993) proposed in his study that operating cash flow and reported earnings are commonly used by analysts as a measure of earnings quality. By studying the information content of earnings and operating cash flow in relation to earnings performance, (Cheng, Liu, \& Schaefer, 1996) deduced a negative relationship between earnings performance and the information content of operating cash flow and a positive relationship between earnings performance and the information content of earnings.

(Rayburn, 1986) tested the association between accruals, operating cash flow and stock returns. The study results reinforce the consistency in the association. Nonetheless, he noted that long-term accruals do not have information content as current accruals have; which was noted by (Wilson, 1986) as well. (Chan et al., 2004) used accruals to measure the quality of earnings in their study. They inferred a negative relationship between accruals and stock returns, justifying that investors link high accruals to management manipulations. (Houge \& Loughran, 2000) concluded that investors fixate on current earnings ignoring the importance of cash flow persistence on the long term which lowers the quality of earnings as both accruals and cash flow are important components in interpreting earnings.

\section{Methodology}

\subsection{Study Variables and Model}

Mainly the study includes two main variables; market stock returns (dependent variable) and earnings per share deflated by stock price (independent variable). In addition, the study includes one control variable which is the companies' age. Dummy variables are used in this study for the purpose of classifying and dividing data into 
subgroups according to their performance. Data of the dependent and the independent variables are different for each indicator according to the sorting criteria of each indicator. The classification of the dependent and the independent variables is influenced by the calculation results of the indicators. The study variables are measured as follows:

- $\quad$ Market stock returns $\left(R E T_{i t}\right)$ is calculated by measuring the monthly stock return $\left(R_{i \tau}\right)$ for company $i$ in month $\tau$ (the window starts in May for year $t$ till April for year $t+1$ ) first;

$$
R_{i \tau}=\left(P_{i \tau}-P_{i \tau-1}\right) / P_{i \tau-1}
$$

Where $\quad P_{i \tau}=$ the monthly closing stock price for company $i$ in month $\tau$.

$P_{i \tau-1}=$ the monthly closing stock price for company $i$ in month $\tau-1$.

Then the monthly stock return will be cumulated for 12 months in order to calculate the annual stock return. This method was used by (Al-Debi'e and Abu Nassar (1999).

$$
R E T_{i t}=\prod_{\tau=1}^{12}\left(1+R_{i \tau}\right)-1
$$

Where $R E T_{i t}=$ the annual stock return for company $i$ (Monthly cumulative returns for

12 months) for year $t$.

$\Pi=$ the product of 12 months of stock returns.

$R_{i \tau}=$ Monthly stock return for company $i$ month $\tau$.

- $\quad$ Earnings per share (EPS) for year $t$ deflated by the stock price for year $t-1$.

$$
X_{i t}=E P S_{i t} / P_{i t-1}
$$

Where $\quad E P S_{i t}=$ the annual earnings per share for company $i$. It is calculated through

dividing the earnings available for the common stockholders for year $t$ by the

weighted average number of common shares outstanding for the same year.

$P_{i t-1}=$ the company closing stock price at the beginning of the window.

- The control variable of the study is the age of companies. Companies are classified based on their age into young companies (lowest $40 \%$ ages; companies that age from 3 to 18 years) and old companies (highest $40 \%$ ages; companies that age from 21 to 74 years). Middle $20 \%$ ages are eliminated from the study when the age of companies is considered.

- Dummy Variables, there are two constructions of dummies in this study; for which each is used separately and for a different purpose. The first one uses dummies of " 1 " (good performance) and " 0 " (bad performance) for the purpose of classifying companies' performance for each year under each indicator. A summary indicator is used to conclude the results of the dummy variables over the five indicators. This summary shows the company score out of 5 based on the five earnings quality measures.

The second dummies are used only for the first and second indicators (cash flow to accruals and cash flow to operating income indicators) for the purpose of overcoming the negative sign issue while sorting data. Multiple dummies are used for those indicators as they contain three categories based on the numerator and the denominator signs; the first category where both are positive, the second category where both are negative and the third category where one is positive and the other is negative.

To evaluate the earnings quality effect on the returns-earnings relationship, the following (OLS) is used in this study.

$$
R E T_{i t}=\alpha_{0}+\alpha_{1} X_{i t} / P_{0}+\varepsilon
$$

Where $R E T_{i t}=$ the market stock return for company $i$ in year $t$.

$\alpha_{0}, \alpha_{1}=$ the model's coefficients

$X_{i t}=$ the EPS (Earnings per share) for company $i$ in year $t$.

$P_{0}=$ the company closing stock price at the beginning of the window.

$\varepsilon=$ error term in the regression model.

The five indicators of the study are calculated as follows;

(1) Cash Flow to Accruals Indicator; is calculated through dividing operating cash flow by net income for year $t$, company $i$

$$
\text { OCF to } N I_{i t}=O C F_{i t} / N I_{i t}
$$


(2) Cash Flow to Operating Income Indicator; is calculated through dividing operating cash flow by operating income for year $t$, company $i$

$$
\text { OCF to OI } I_{i t}=O C F_{i t} / O I_{i t}
$$

(3) The Stability of Earnings Indicator; Z-score is used for measuring the stability of earnings by subtracting the mean of net income for the company $i$ over the 11 years from net income for company $i$ in year $t$, then divide the result by the standard deviation of net income for the company over the 11 years.

$$
\mathrm{Z}_{i t}=\left(X_{i t}-\mu\right) / \sigma
$$

(4) The Trend of Earnings Indicator; is measured by calculating the first difference in earnings. Net income for year $t-1$ is subtracted from net income for year $t$.

$$
\text { First } \Delta \text { in Earnings } \text { Et }_{i t}=N I_{i t}-N I_{i t-1}
$$

(5) The Source of Earnings Indicator; is calculated through dividing the absolute value of non-operating income by the absolute value of net income for year $t$ company $i$.

$$
\text { Non operating income to } N I_{i t}=\mid \text { Non operating income } e_{i t}|/| N I_{i t} \mid
$$

There are two main groups of the study which are used to sort data based on the quality of their earnings

- Top $40 \%$ group; which includes the highest $40 \%$ observations of the sorted data. The observations of this group represent data with higher quality than the latter group.

- Worst 40\% group; which includes the lowest $40 \%$ observations of the sorted data. The observations of this group represent data with lower quality than the former group.

The residual $20 \%$ of observations is eliminated from the study as it represents the moderate results for each indicator.

\subsection{Study Sample}

The study sample includes 120 industrial and service Jordanian companies out of 126 industrial and service companies listed in Amman Stock Exchange (ASE) during the period (2002-2012); where 66 companies are from the industrial sector and 54 companies are from the service sector as in the year 2013. Financial and insurance companies are excluded as they are subject to special regulations. The study sample is selected based on the availability of data needed for calculating the study variables for at least two consecutive years. As a result, four industrial companies and two service companies out of total companies are excluded from the study sample because of the unavailability of variables data over the study period. Total number of observations, after excluding the missing data of stock returns and earnings per share (EPS), is 1022 observations. However, total number of observations, after excluding the outliers of the study variables and indicators, is 882 observations (534 for industrial companies and 348 for service companies). Outliers were excluded based on the $1^{\text {st }}$ percentile and $99^{\text {th }}$ percentile.

\subsection{Descriptive Statistics}

Table (1) presents the descriptive statistics for the stock returns, deflated earnings per share (EPS) and the control variable (company's age). Table (2) presents the descriptive statistics for the five indicators; cash flow to accruals, cash flow to operating income, the stability of earnings, the trend of earnings and the source of earnings respectively. Table (3) presents the descriptive statistics for all observations before excluding the outliers.

Table 1. Descriptive Statistics for Main Variables and Control Variable of the Study for the Period (2002-2012)

\begin{tabular}{lccc}
\hline & Deflated EPS & Market Stock Return & Company's Age \\
Variable $X_{i t} / P_{0}$ & Variable $R E T_{i t}$ & 4 \\
Min & $(0.743)$ & $(0.696)$ & 74 \\
Max & 0.285 & 2.873 & 26.651 \\
Mean & 0.011 & 0.056 & 21 \\
Median & 0.036 & $(0.037)$ & 15.068 \\
SD & 0.118 & 0.472 & 882 \\
Number of Observations & 882 & 882 & Outliers were not \\
$1^{\text {st }}$ Percentile \& 99th Percentile are calculated before excluding the outliers (as outliers are excluded based on them) \\
$1^{\text {st }}$ Percentile & $(0.761)$ & $(0.702)$ & excluded based on \\
99th Percentile & 0.298 & 2.944 & control variable \\
Number of Observations & 1022 & 1022 & 1022 \\
\hline
\end{tabular}


Table (1) presents the descriptive statistics for main variables and control variable of the study over the study period. Total number of observations before excluding the outliers is 1022 observations. Total number of observations is 882 observations after excluding the outliers, where values under $1^{\text {st }}$ percentile and values above $99^{\text {th }}$ percentile are excluded from the study sample. The lowest value of deflated EPS is (0.743) whilst the highest value of deflated EPS is 0.285 . Moreover, deflated EPS has a mean of 0.011 , a median of 0.036 and SD of 0.118 . This indicates that deflated EPS deviates from an average of 0.011 by 0.118 to both sides. On the other hand, the mean of market stock returns is 0.056 . Stock returns deviate from the average by a standard deviation by 0.472 to both sides. Stock returns data have a median of (0.037). The highest and lowest values of market stock returns among the study sample are JOD 2.873 and JOD (0.696) respectively. The newest companies among the companies sample are 4-year old. The oldest company is 74-year old. Companies' age has a mean of 26.651, a median of 21 and SD of 15.068.

Table 2. Descriptive Statistics for the Five Indicators of Earnings Quality for the Period (2002-2012)

\begin{tabular}{lccccc}
\hline & $\begin{array}{l}\text { Indicator (1) } \\
\text { OCF to NI ratio }\end{array}$ & $\begin{array}{c}\underline{\text { Indicator (2) }} \\
\text { OCF to OI ratio }\end{array}$ & $\begin{array}{c}\underline{\text { Indicator (3) }} \\
\text { Z-scores of NI }\end{array}$ & $\begin{array}{c}\underline{\text { Indicator (4) }} \\
\text { First } \Delta \text { in NI } \\
\text { (JOD) }\end{array}$ & $\begin{array}{c}\text { Indicator (5) } \\
\text { Non-operating } \\
\text { income to NI ratio }\end{array}$ \\
\hline Min & $(36.686)$ & $(49.282)$ & $(2.325)$ & $(17,147,459)$ & 0.001 \\
Max & 24.732 & 30.521 & 1.956 & $25,170,446$ & 11.296 \\
Mean & 0.372 & 0.164 & 0.049 & 167,352 & 0.797 \\
Median & 0.569 & 0.514 & 0.156 & 26,457 & 0.376 \\
SD & 5.064 & 4.779 & 0.881 & $2,754,872$ & 1.323 \\
Table 2 (cont.) & & & & & 882 \\
Number of & 882 & 882 & 882 & 882 & \\
Observations & & & & &
\end{tabular}

$1^{\text {st }}$ Percentile \& 99th Percentile are calculated before excluding the outliers (as outliers are excluded based on them)

Table 2 (cont.)

\begin{tabular}{|c|c|c|c|c|c|}
\hline & $\frac{\text { Indicator (1) }}{\text { OCF to NI ratio }}$ & $\frac{\text { Indicator (2) }}{\text { OCF to OI ratio }}$ & $\frac{\text { Indicator (3) }}{\text { Z-scores of NI }}$ & $\begin{array}{l}\text { Indicator (4) } \\
\text { First } \Delta \text { in NI } \\
(\text { JOD })\end{array}$ & $\begin{array}{c}\underline{\text { Indicator (5) }} \\
\text { Non-operating } \\
\text { income to NI ratio }\end{array}$ \\
\hline $1^{\text {st }}$ percentile & (38.657) & $(51.720)$ & $(2.362)$ & $(17,222,233)$ & 0.001 \\
\hline $99^{\text {th }}$ percentile & 28.691 & 30.592 & 1.976 & $25,316,504$ & 15.640 \\
\hline $\begin{array}{l}\text { Number of } \\
\text { Observations }\end{array}$ & 1022 & 1022 & 1022 & 1022 & 1022 \\
\hline
\end{tabular}

Table (2) shows the descriptive statistics for the five indicators as calculated for the measurement unit of each indicator. Total number of observations for each indicator is 882 observations after excluding the outliers based on the 1 st percentile and the 99th percentile. For total number of observations; 1022 observations, observations below (38.657) and above 28.691 are excluded from OCF to NI ratio data, observations below (51.720) and above 30.592 are excluded from OCF to OI ratio data, observations below (2.362) and above 1.976 are excluded from Z-scores of NI data, observations below $(17,222,233)$ and above $25,316,504$ are excluded from first change in NI data and observations below 0.001 and above 15.640 are excluded from non-operating income to NI ratio data.

First, OCF to NI ratio data has a mean of 0.372 , median of 0.569 and SD of 5.064 which indicates that OCF to NI ratio deviates from average by approximately 5.064 to both sides. The highest value of OCF to NI ratio, after excluding outliers, is 24.732 whereas the lowest value is (36.686).

Second, the lowest and highest values of OCF to OI ratio are (49.282) and 30.521respectively. Moreover, the ratio has a mean of 0.164 , a median of 0.514 and SD of 4.779 . Third, Z-scores of NI data have mean, median, SD of $0.049,0.156$ and 0.881 respectively. Maximum and minimum values of Z-scores of NI are 1.956 and (2.325) respectively.

Fourth, the first change in NI data that is used to calculate the trend of earnings has a mean of $167 \mathrm{~K}$, median of $26 \mathrm{~K}$ and SD of 2,754K. Maximum value registered for the first change in NI is JOD 25,170K while the minimum value is JOD $(17,147 \mathrm{~K})$.

Fifth, the highest value of non-operating income to NI ratio is 11.296 whereas the lowest value of the ratio is 0.001 . Mean, median and SD of the ratio are $0.797,0.376$ and 1.323 respectively. 
Table 3. Descriptive Statistics for all observations (1022 observations) before excluding outliers for the Period (2002-2012)

\begin{tabular}{lccccccc}
\hline & $\begin{array}{c}\text { Deflated } \\
\text { EPS } \\
\text { Variable } \\
X_{i t} / P_{0}\end{array}$ & $\begin{array}{c}\text { Market Stock } \\
\text { Return } \\
\text { Variable } \\
R E T_{i t}\end{array}$ & $\begin{array}{c}\text { OCF to } \\
\text { NI ratio }\end{array}$ & $\begin{array}{c}\text { OCF to OI } \\
\text { ratio }\end{array}$ & $\begin{array}{c}\text { Z-scores } \\
\text { of NI }\end{array}$ & $\begin{array}{c}\Delta \text { in NI } \\
\text { (JOD) }\end{array}$ & $\begin{array}{c}\text { Non-operating } \\
\text { income to NI } \\
\text { ratio }\end{array}$ \\
\hline Min & $(1.227)$ & $(0.900)$ & $(549.93)$ & $(2894.5)$ & $(2.908)$ & $(179 \mathrm{M})$ & 0 \\
Max & 2.239 & 19.555 & 353.91 & 1375.3 & 2.968 & $192 \mathrm{M}$ & 239.78 \\
Mean & 0.004 & 0.128 & 0.023 & $(2.299)$ & 0.010 & $283 \mathrm{~K}$ & 1.488 \\
Median & 0.033 & $(0.039)$ & 0.429 & 0.445 & 0.115 & $22 \mathrm{~K}$ & 0.389 \\
SD & 0.180 & 1.018 & 26.423 & 102.03 & 0.955 & $14 \mathrm{M}$ & 9.392 \\
$1^{\text {st }}$ percentile & $(0.761)$ & $(0.702)$ & $(38.657)$ & $(51.720)$ & $(2.362)$ & $(17 \mathrm{M})$ & 0.001 \\
$99^{\text {th }}$ & 0.298 & 2.944 & 28.691 & 30.592 & 1.976 & $25 \mathrm{M}$ & 15.640 \\
percentile & & & & & & & 1022 \\
Number of & 1022 & 1022 & 1022 & 1022 & 1022 & & 1022 \\
Observations & & & & & & & \\
\hline
\end{tabular}

Table (3) presents the descriptive statistics for the study variables and indicators for all observations (1022 observations) before excluding the outliers.

\section{Results}

\subsection{Study Results of Returns-Earnings Relationship for all data}

The study uses Ordinary Least-Squares Regression (OLS) for the purpose of finding out whether high-quality earnings companies have stronger returns-earnings relationship than low-quality earnings companies. Adjusted- $R^{2}$ and earnings response coefficient (ERC) are the analysis tools of the study.

Table 4. Results of the Returns-Earnings Relationship for All Data

\begin{tabular}{|c|c|c|c|c|c|c|c|c|c|c|c|}
\hline & \multirow{2}{*}{$\begin{array}{c}\text { Benchmark } \\
\text { All }\end{array}$} & \multicolumn{2}{|c|}{$\begin{array}{l}\text { Cash Flow to } \\
\text { Accruals }\end{array}$} & \multicolumn{2}{|c|}{$\begin{array}{l}\text { Cash Flow to } \\
\text { Operating } \\
\text { Income }\end{array}$} & \multicolumn{2}{|c|}{$\begin{array}{l}\text { Stability of } \\
\text { Earnings }\end{array}$} & \multicolumn{2}{|c|}{$\begin{array}{l}\text { Trend of } \\
\text { Earnings }\end{array}$} & \multicolumn{2}{|c|}{$\begin{array}{l}\text { Source of } \\
\text { Earnings }\end{array}$} \\
\hline & & $\begin{array}{l}\text { Top } \\
40 \%\end{array}$ & $\begin{array}{l}\text { Worst } \\
\mathbf{4 0 \%}\end{array}$ & $\begin{array}{l}\text { Top } \\
\mathbf{4 0 \%}\end{array}$ & $\begin{array}{l}\text { Worst } \\
40 \%\end{array}$ & $\begin{array}{l}\text { Top } \\
\mathbf{4 0 \%}\end{array}$ & $\begin{array}{l}\text { Worst } \\
\mathbf{4 0 \%}\end{array}$ & $\begin{array}{l}\text { Top } \\
40 \%\end{array}$ & $\begin{array}{l}\text { Worst } \\
\mathbf{4 0 \%}\end{array}$ & $\begin{array}{l}\text { Top } \\
\mathbf{4 0 \%}\end{array}$ & $\begin{array}{l}\text { Worst } \\
40 \%\end{array}$ \\
\hline$\alpha_{1}$ & 0.911 & 3.606 & 0.502 & 2.109 & 0.552 & 2.853 & 0.676 & 0.933 & 0.452 & 1.107 & 0.808 \\
\hline Adjusted- $R^{2}$ & 0.050 & 0.158 & 0.020 & 0.085 & 0.024 & 0.117 & 0.037 & 0.026 & 0.030 & 0.056 & 0.038 \\
\hline Observations & 882 & 353 & 353 & 353 & 353 & 353 & 353 & 353 & 353 & 353 & 353 \\
\hline \multicolumn{12}{|c|}{ Young companies } \\
\hline$\alpha_{1}$ & 0.755 & 3.340 & $(0.377)$ & 2.241 & $(0.387)$ & 4.974 & $(0.204)$ & 0.529 & 0.248 & 0.695 & 0.767 \\
\hline Adjusted- $R^{2}$ & 0.018 & 0.179 & 0.002 & 0.078 & 0.002 & 0.237 & $(0.005)$ & $(0.002)$ & $(0.001)$ & 0.008 & 0.012 \\
\hline Observations & 338 & 135 & 135 & 135 & 135 & 135 & 135 & 135 & 135 & 135 & 135 \\
\hline \multicolumn{12}{|c|}{ Old companies } \\
\hline$\alpha_{1}$ & 1.007 & 3.638 & 0.871 & 2.919 & 0.835 & 1.536 & 0.903 & 1.027 & 0.556 & 1.472 & 0.533 \\
\hline Adjusted- $R^{2}$ & 0.077 & 0.162 & 0.071 & 0.123 & 0.070 & 0.045 & 0.087 & 0.049 & 0.043 & 0.168 & 0.017 \\
\hline Observations & 447 & 179 & 179 & 179 & 179 & 179 & 179 & 179 & 179 & 179 & 179 \\
\hline
\end{tabular}

Table (4) reports the results of the regression model for all data for the five indicators before and after adding the control variable; age of companies.

For all companies, regardless of their age, the highest value of Adjusted- $R^{2}$ among top $40 \%$ groups is scored by cash flow to accruals indicator for a value of 0.158 . However, the stability of earnings indicator has the second high score for a value of 0.117 followed by cash flow to operating income indicator for a value of 0.085 and the source of earnings indicator for a value of 0.056 . The lowest value of Adjusted $-R^{2}$ among top $40 \%$ groups is scored by the trend of earnings indicator for a value of 0.026. Results for all data regardless of their age reveal that the returns-earnings relationship for top $40 \%$ group is stronger than the relationship for worst $40 \%$ group for all 
indicators except for the trend of earnings indicator. For young companies, the highest value of Adjusted- $R^{2}$ among top $40 \%$ groups is scored by the stability of earnings indicator for a value of 0.237 . However, the lowest values of Adjusted- $R^{2}$ for top $40 \%$ groups scored by the source of earnings indicator; 0.008 and the trend of earnings indicator; (0.002). Those results indicate that the stability of earnings indicator has the strongest effect on improving the returns-earnings relationship for companies that age from 0 to 18 years. The big difference between the values of top $40 \%$ groups and worst $40 \%$ groups supports the assumption that the stability of earnings and high ratios of OCF to NI strengthen the returns-earnings relationship.

On the other hand, among top $40 \%$ groups of old companies, the highest Adjusted- $R^{2}$ is 0.168 scored by the source of earnings indicator while the lowest value is 0.045 scored by the stability of earnings indicator. In general, the results indicate that the stability of earnings indicator does not affect investors' decisions for companies that age 21 years or above. In general, earnings response coefficient values for the five indicators are greater for top $40 \%$ groups than the benchmark values.

\subsection{Study Results of Returns-Earnings Relationship for Industrial data}

Table 5. Results of the Returns-Earnings Relationship for Industrial Data

\begin{tabular}{|c|c|c|c|c|c|c|c|c|c|c|c|}
\hline & \multirow{2}{*}{$\begin{array}{c}\begin{array}{c}\text { Benchmar } \\
\mathrm{k}\end{array} \\
\text { All }\end{array}$} & \multicolumn{2}{|c|}{$\begin{array}{l}\text { Cash Flow to } \\
\text { Accruals }\end{array}$} & \multicolumn{2}{|c|}{$\begin{array}{l}\text { Cash Flow to } \\
\text { Operating } \\
\text { Income }\end{array}$} & \multicolumn{2}{|c|}{$\begin{array}{l}\text { Stability of } \\
\text { Earnings }\end{array}$} & \multicolumn{2}{|c|}{$\begin{array}{l}\text { Trend of } \\
\text { Earnings }\end{array}$} & \multicolumn{2}{|c|}{$\begin{array}{l}\text { Source of } \\
\text { Earnings }\end{array}$} \\
\hline & & $\begin{array}{l}\text { Top } \\
\mathbf{4 0 \%}\end{array}$ & $\begin{array}{l}\text { Worst } \\
40 \%\end{array}$ & $\begin{array}{l}\text { Top } \\
40 \%\end{array}$ & $\begin{array}{l}\text { Worst } \\
40 \%\end{array}$ & $\begin{array}{l}\text { Top } \\
40 \%\end{array}$ & $\begin{array}{l}\text { Worst } \\
\mathbf{4 0 \%}\end{array}$ & $\begin{array}{l}\text { Top } \\
\mathbf{4 0 \%}\end{array}$ & $\begin{array}{c}\text { Wors } \\
t \\
40 \%\end{array}$ & $\begin{array}{l}\text { Top } \\
\mathbf{4 0 \%}\end{array}$ & $\begin{array}{c}\text { Wors } \\
t \\
40 \%\end{array}$ \\
\hline$\alpha_{1}$ & 0.800 & $\begin{array}{c}3.66 \\
1\end{array}$ & 0.313 & $\begin{array}{c}1.78 \\
5\end{array}$ & 0.333 & $\begin{array}{c}2.46 \\
0\end{array}$ & 0.444 & 0.696 & 0.369 & 0.737 & 0.842 \\
\hline Adjusted- $R^{2}$ & 0.037 & $\begin{array}{c}0.13 \\
7\end{array}$ & 0.002 & $\begin{array}{c}0.06 \\
6\end{array}$ & 0.003 & $\begin{array}{c}0.07 \\
7\end{array}$ & 0.013 & 0.006 & 0.023 & 0.021 & 0.041 \\
\hline $\begin{array}{c}\text { Observation } \\
\mathrm{s}\end{array}$ & 534 & 214 & 214 & 214 & 214 & 214 & 214 & 214 & 214 & 214 & 214 \\
\hline \multicolumn{12}{|c|}{ Young companies } \\
\hline$\alpha_{1}$ & 0.423 & $\begin{array}{c}5.44 \\
0\end{array}$ & $\begin{array}{c}(1.929 \\
)\end{array}$ & $\begin{array}{c}2.37 \\
6\end{array}$ & $\begin{array}{c}(1.789 \\
)\end{array}$ & $\begin{array}{c}5.30 \\
2\end{array}$ & $\begin{array}{c}(0.677 \\
)\end{array}$ & $\begin{array}{c}(0.406 \\
)\end{array}$ & 0.414 & $\begin{array}{c}(0.381 \\
)\end{array}$ & 0.896 \\
\hline Adjusted- $R^{2}$ & 0.0008 & $\begin{array}{c}0.19 \\
5\end{array}$ & 0.178 & $\begin{array}{c}0.07 \\
6\end{array}$ & 0.155 & $\begin{array}{c}0.18 \\
2\end{array}$ & 0.018 & $\begin{array}{c}(0.013 \\
)\end{array}$ & 0.015 & $\begin{array}{c}(0.012 \\
)\end{array}$ & 0.019 \\
\hline $\begin{array}{c}\text { Observation } \\
\mathrm{s}\end{array}$ & 152 & 61 & 61 & 61 & 61 & 61 & 61 & 61 & 61 & 61 & 61 \\
\hline \multicolumn{12}{|c|}{ Old companies } \\
\hline$\alpha_{1}$ & 0.958 & $\begin{array}{c}3.42 \\
4\end{array}$ & 0.964 & $\begin{array}{c}2.79 \\
2\end{array}$ & 0.944 & $\begin{array}{c}1.30 \\
6\end{array}$ & 0.702 & 1.296 & 0.316 & 1.466 & 0.482 \\
\hline Adjusted- $R^{2}$ & 0.067 & $\begin{array}{c}0.14 \\
3\end{array}$ & 0.073 & $\begin{array}{c}0.11 \\
1\end{array}$ & 0.069 & $\begin{array}{c}0.03 \\
0\end{array}$ & 0.053 & 0.053 & 0.008 & 0.156 & 0.008 \\
\hline $\begin{array}{c}\text { Observation } \\
\text { s }\end{array}$ & 300 & 120 & 120 & 120 & 120 & 120 & 120 & 120 & 120 & 120 & 120 \\
\hline
\end{tabular}

Table (5) reports the results of industrial data before and after including the companies' age. Before including the control variable, the highest value of Adjusted- $R^{2}$ among top $40 \%$ groups is scored by cash flow to accruals indicator for a value of 0.137 where the lowest value of Adjusted- $R^{2}$ among top $40 \%$ groups is scored by the trend of earnings indicator for a value of 0.006. For young industrial companies, the highest value of Adjusted- $R^{2}$ is scored by cash flow to accruals indicator for a value of 0.195 . On the other hand, the trend of earnings indicator and the source of earnings indicator scored negative values of Adjusted- $R^{2},(0.013)$ and $(0.012)$ respectively. For old companies, the source of earnings indicator has scored the highest value of Adjusted- $R^{2}$, among top $40 \%$ groups, for a value of 0.156 followed by an approximate value of 0.143 scored by cash flow to accruals indicator. However, the trend and stability of earnings indicators have the lowest values of Adjusted- $R^{2}$ among top $40 \%$ groups; 0.053 and 0.030 respectively. As mentioned above, cash flow to accruals indicator has the strongest effect on improving the 
returns-earnings relationship for young industrial companies and for all industrial companies regardless of their age. However, the source of earnings indicator has the strongest effect on improving the relationship for old companies. The reactions of stock returns to the changes in earnings for top $40 \%$ groups of industrial data were stronger than the reactions for worst $40 \%$ groups except for the source of earnings indicator before including the control variable and for the source and trend of earnings indicators for young companies.

4.3 Study Results of Returns-Earnings Relationship for Service data

Table 6. Results of the Returns-Earnings Relationship for Service Data

\begin{tabular}{|c|c|c|c|c|c|c|c|c|c|c|c|}
\hline & \multirow{2}{*}{$\begin{array}{c}\text { Benchmark } \\
\text { All }\end{array}$} & \multicolumn{2}{|c|}{$\begin{array}{c}\text { Cash Flow to } \\
\text { Accruals }\end{array}$} & \multicolumn{2}{|c|}{$\begin{array}{l}\text { Cash Flow to } \\
\text { Operating } \\
\text { Income }\end{array}$} & \multicolumn{2}{|c|}{$\begin{array}{l}\text { Stability of } \\
\text { Earnings }\end{array}$} & \multicolumn{2}{|c|}{$\begin{array}{l}\text { Trend of } \\
\text { Earnings }\end{array}$} & \multicolumn{2}{|c|}{$\begin{array}{l}\text { Source of } \\
\text { Earnings }\end{array}$} \\
\hline & & $\begin{array}{l}\text { Top } \\
40 \%\end{array}$ & $\begin{array}{l}\text { Worst } \\
40 \%\end{array}$ & $\begin{array}{l}\text { Top } \\
\text { 40\% }\end{array}$ & $\begin{array}{l}\text { Worst } \\
40 \%\end{array}$ & $\begin{array}{l}\text { Top } \\
\text { 40\% }\end{array}$ & $\begin{array}{l}\text { Worst } \\
40 \%\end{array}$ & $\begin{array}{l}\text { Top } \\
40 \%\end{array}$ & $\begin{array}{l}\text { Worst } \\
40 \%\end{array}$ & $\begin{array}{l}\text { Top } \\
40 \%\end{array}$ & $\begin{array}{c}\text { Worst } \\
40 \%\end{array}$ \\
\hline$\alpha_{1}$ & 1.166 & 3.545 & 0.857 & 3.281 & 0.994 & 3.641 & 1.067 & 1.178 & 0.625 & 1.781 & 0.710 \\
\hline Adjusted- $R^{2}$ & 0.082 & 0.122 & 0.062 & 0.137 & 0.083 & 0.223 & 0.082 & 0.063 & 0.031 & 0.149 & 0.022 \\
\hline Observations & 348 & 139 & 139 & 139 & 139 & 139 & 139 & 139 & 139 & 139 & 139 \\
\hline \multicolumn{12}{|c|}{ Young companies } \\
\hline$\alpha_{1}$ & 1.455 & 2.772 & 1.359 & 2.625 & 1.282 & 4.763 & 1.155 & 2.624 & $(0.107)$ & 1.992 & 0.365 \\
\hline Adjusted- $R^{2}$ & 0.058 & 0.058 & 0.080 & 0.096 & 0.069 & 0.266 & 0.020 & 0.092 & $(0.013)$ & 0.128 & $(0.011)$ \\
\hline Observations & 186 & 74 & 74 & 74 & 74 & 74 & 74 & 74 & 74 & 74 & 74 \\
\hline \multicolumn{12}{|c|}{ Old companies } \\
\hline$\alpha_{1}$ & 1.102 & 4.375 & 0.945 & 3.734 & 0.925 & 2.414 & 1.146 & 0.488 & 1.107 & 1.710 & 0.588 \\
\hline Adjusted- $R^{2}$ & 0.089 & 0.188 & 0.079 & 0.169 & 0.081 & 0.080 & 0.119 & 0.010 & 0.111 & 0.206 & 0.017 \\
\hline Observations & 147 & 59 & 59 & 59 & 59 & 59 & 59 & 59 & 59 & 59 & 59 \\
\hline
\end{tabular}

Table (6) reports the results for service data. The highest value of Adjusted- $R^{2}$ for service data regardless of their age is scored by the stability of earnings indicator for a value of 0.223 whereas the lowest is scored by the trend of earnings indicator. Likewise, the stability of earnings indicator scored the highest value of Adjusted- $R^{2}$ among top $40 \%$ groups of young companies for a value of 0.266 . The lowest value of Adjusted- $R^{2}$, among top $40 \%$ groups, is scored by cash flow to accruals indicator for a value of 0.058 . However, for old companies, the highest and lowest values of Adjusted- $R^{2}$ are scored by the source of earnings indicator; 0.206 and the trend of earnings indicator; 0.010 respectively. Earnings response coefficient values for top $40 \%$ groups of service data are greater than the values for worst $40 \%$ groups except for the trend of earnings indicator for old companies. In addition, values of earnings response coefficient for top $40 \%$ groups of service data exceeded benchmark values except for the trend of earnings indicator for old companies.

\subsection{Study Results for Summary Indicator}

One of the approaches of this study is that it generates a summary indicator of companies' earnings quality. The Summary indicator summarizes the annual quality of earnings for each company based on the five measures of earnings quality that are used in the study (cash flow to accruals, cash flow to operating income, the stability of earnings, the trend of earnings and the source of earnings). The annual quality of earnings for companies is presented by a score out of 5; where 5 is an excellent quality of earnings, 4 is very good, 3 is good, 2 is acceptable, 1 is bad and 0 is a very bad quality of earnings. 
Table 7. Summary of the Results for Summary Indicator of the Five Indicators

\begin{tabular}{|c|c|c|c|c|c|c|}
\hline & \multicolumn{2}{|c|}{ All Data } & \multicolumn{2}{|c|}{ Industrial Data } & \multicolumn{2}{|c|}{ Service Data } \\
\hline Observations that scored $\mathbf{5} / \mathbf{5}$ & 115 & $13 \%$ & 46 & $9 \%$ & 69 & $20 \%$ \\
\hline Observations that scored 4 / 5 & 131 & $15 \%$ & 75 & $14 \%$ & 56 & $16 \%$ \\
\hline Observations that scored $\mathbf{3} / \mathbf{5}$ & 231 & $26 \%$ & 149 & $28 \%$ & 82 & $24 \%$ \\
\hline Observations that scored $\mathbf{2} / \mathbf{5}$ & 195 & $22 \%$ & 125 & $23 \%$ & 70 & $20 \%$ \\
\hline Observations that scored $\mathbf{1} / \mathbf{5}$ & 189 & $21 \%$ & 128 & $24 \%$ & 61 & $18 \%$ \\
\hline Observations that scored $\mathbf{0} / \mathbf{5}$ & 21 & $3 \%$ & 11 & $2 \%$ & 10 & $2 \%$ \\
\hline Mean & \multicolumn{2}{|c|}{2.688} & \multicolumn{2}{|c|}{2.537} & \multicolumn{2}{|c|}{2.919} \\
\hline Standard Deviation & \multicolumn{2}{|c|}{1.366} & \multicolumn{2}{|c|}{1.285} & \multicolumn{2}{|c|}{1.454} \\
\hline Total number of Observations & \multicolumn{2}{|c|}{882} & \multicolumn{2}{|c|}{534} & \multicolumn{2}{|c|}{348} \\
\hline
\end{tabular}

Table (7) presents the summary indicator results for the five Indicators. Most observations are scattered around 1, 2 and 3 scores for all data and industrial data. However, for service data observations are scattered around the five scores.

Table 8. Results of the Returns-Earnings Relationship for Summary Indicator

\begin{tabular}{ccccccc}
\hline & \multicolumn{2}{c}{ All Data } & \multicolumn{2}{c}{ Industrial Data } & \multicolumn{2}{c}{ Service Data } \\
\hline & Top 40\% & Worst 40\% & Top 40\% & Worst 40\% & Top 40\% & Worst 40\% \\
$\boldsymbol{\alpha}$ & -0.041 & 0.015 & 0.004 & 0.019 & $(0.207)$ & 0.010 \\
$\boldsymbol{\alpha}_{\mathbf{1}}$ & 2.585 & 0.714 & 2.198 & 0.670 & 4.383 & 0.796 \\
${\text { Adjusted- } \boldsymbol{R}^{\mathbf{2}}}_{\text {Observations }}^{0.074}$ & 0.050 & 0.064 & 0.046 & 0.190 & 0.052 \\
\hline
\end{tabular}

Table (8) presents the results of the regression model for the summary indicator. For all data, top $40 \%$ group has an Adjusted- $\mathrm{R}^{2}$ for a value of 0.074 while worst $40 \%$ group has a value of 0.050 . This indicates that companies who scored from 3 to 5 out of 5 (which are top $40 \%$ observations) have a stronger returns-earnings relationship than companies who scored from 0 to 2 (which are worst $40 \%$ observations). On the contrary, Adjusted- $\mathrm{R}^{2}$ values for industrial companies are slightly lower than all data values; as Adjusted $-\mathrm{R}^{2}$ values are 0.064 for top $40 \%$ group and 0.046 for worst $40 \%$ group. Service data recorded the highest value of Adjusted- $\mathrm{R}^{2}$ for top $40 \%$ group; 0.190 whereas for worst $40 \%$ group the value is 0.052 . This indicates that top $40 \%$ group of service data has the strongest returns-earnings relationship among all sets of data.

ERC values for top $40 \%$ groups of all data, industrial data and service data are relatively high $2.585,2.198$ and 4.383 respectively. However, ERC values for worst $40 \%$ groups are lower than 1 as for all data the value is 0.714 , for industrial data the value is 0.670 and for service data the value is 0.796 .

In general, for the three sets of data, Adjusted- $\mathrm{R}^{2}$ and ERC values for top $40 \%$ groups ( 3 to 5 out of 5 scores) have outperformed the values for worst $40 \%$ groups ( 0 to 2 out of 5 scores).

\section{Conclusion}

Mainly, the study aimed to examine the effect of earnings quality (measured using five indicators) on the returns-earnings relationship. Based on the study results, Cash flow to accruals indicator, the stability of earnings indicator and the source of earnings indicator are the most effective indicators in enhancing the returns-earnings relationship. Cash flow to accruals indicator is effective for young companies and all companies regardless of their age (for industrial data and for all data before dividing them into industrial data and service data), as most companies aim to have financial solvency, after gaining profit. As a result, companies focus on improving both components of earnings; the cash component and accruals component. Likewise, the stability of earnings indicator is effective for young companies and all companies regardless of their age (for service data and for all data before dividing them into industrial data and service data), this could be due to the focus investors place on young companies as they expect that their earnings are unstable because those companies are in the growth phase. Earnings instability affects the pattern of earnings. However, Old companies have stable earnings which lead to a good pattern of earnings. In addition, market participants focus on young companies because they have less information about them. Hence, market stock returns for young companies fluctuate more than market stock returns for old companies. On the other 
hand, source of earnings indicator is the most effective indicator in enhancing the returns-earnings relationship for old companies (for industrial data, service data and for all data before dividing them into industrial data and service data). The results indicate that investors' decisions are affected the most by the source of earnings for old companies. Investors pay more attention to the changes in the components of earnings for companies that are 21 years old or above. However, this indicator is followed by cash flow to accruals indicator and cash flow to operating income indicator as they improve the returns-earnings relationship for old companies in the second and third place respectively.

In general, the indicator that has the weakest effect on the returns-earnings relationship is the trend of earnings indicator. This indicator does not improve the returns-earnings relationship which means that it couldn't be used solely as a measure of earning quality. Generally, there is an improvement on the returns-earnings relationship after including the age of companies as a control variable.

We recommend that stock market participants should avoid fixation on the bottom line number of the Income Statement. The results revealed the importance of other intermediate components of that statement. Therefore, they are advised to use and utilize the five proposed indicators, (cash flow to accruals indicator, cash flow to operating income indicator, the stability of earnings indicator, the trend of earnings indicator and the source of earnings indicator), while assessing the quality of earnings as they are simple, direct and their data are readily available.

Finally, we couldn't compare the results of our study with prior similar work, since no prior empirical work -to our knowledge- has used these indicators to assess the quality of earnings and enhance the returns-earnings relationship. We encourage our colleagues in other countries to replicate and extend our study in order to test whether our results were country-specific or can be enhanced using additional accounting variables.

\section{References}

Abdelghany, K. E. (2005). Measuring the quality of earnings. Managerial Auditing Journal, 20(9), 1001-1015. http://dx.doi.org/10.1108/02686900510625334

Abdelqader, M. B., Al-Debi'e, M. M. \& Gharaibeh, F. A. (2008). The Relation between Earnings and Stock Returns in the Long Run: Replication and Extension. Jordan Journal of Business Administration, 4(1), 24-44.

Al-Debi'e, M. M. \& Abu Nassar, M. (1999). Specification of the Relationship between Stock Returns and the Accounting Earnings of Jordanian Companies. Dirasat, Administration Sciences, 26(2), 312-329.

Ball, R. \& Brown, P. (1968). An Empirical Evaluation of Accounting Income Numbers. Journal of Accounting Research, 6(2), 159-178. http://dx.doi.org/10.2307/2490232

Bernstein, L. (1993). Financial Statement Analysis (5th ed.). Homewood IL: Irwin.

Chan, K., Chan, L. K. C., Jegadeesh, N. \& Lakonishok, J. (2004). Earnings Quality and Stock Returns, Working Paper, University of Illinois, Urbana-Champaign, IL. http://dx.doi.org/10.2139/ssrn.259691

Cheng, C.S.A., Liu, C.S., \& Schaefer, T.F. (1996). Earnings Permanence and the Incremental Information Content of Cash Flows from Operations. Journal of Accounting Research, 34(1), 173-181. http://dx.doi.org/10.2307/2491338

Dechow, P. M., \& Dichev, I. D. (2002). The Quality of Accruals and Earnings: The Role of Accrual Estimation Errors. The Accounting Review, 77(1), 35-59. http://dx.doi.org/10.2308/accr.2002.77.s-1.35

Dechow, P., Ge, W., \& Schrand, C. (2010). Understanding earnings quality: A review of the proxies, their determinants and their consequences. Journal of Accounting and Economics, 50(2-3), 344-401. http://dx.doi.org/10.1016/j.jacceco.2010.09.001

Easton, P. D., \& Harris T. S. (1991). Earnings as an Explanatory Variable of Returns. Journal of Accounting Research, 29(1), 19-36. http://dx.doi.org/10.2307/2491026

Easton, P. D., Harris, T. S., \& Ohlson J. A. (1992). Aggregate Accountings Earnings Can Explain Most of Security Returns: The Case of Long-Return Interval. Journal of Accounting and Economics, 15(2-3), 119-142. http://dx.doi.org/10.1016/0165-4101(92)90015-T

Hodge, F. (2003). Investors' Perceptions of Earnings Quality, Auditor Independence, and the Usefulness of Audited Financial Information. Accounting Horizons (Supplement), 37-48. http://dx.doi.org/10.2308/acch.2003.17.s-1.37

Houge, T. \& Loughran, T. (2000). Cash Flow is King: Cognitive Errors by Investors. Journal of Psychology and Financial Markets, 1(3-4), 161-175. http://dx.doi.org/10.1207/S15327760JPFM0134_2 
King, B. F. (1966). Market and Industry Factors in Stock Price Behavior. Journal of Business, 39(1), 139-190. http://dx.doi.org/10.1086/294847

Kirschenheiter, M. \& Melumad, N. (2004). Earnings' quality and smoothing, Working Paper, Columbia Business School.

Lev, B. (1989). On the Usefulness of Earnings and Earning Research: Lessons and Directions from Two Decades of Empirical Research. Journal of Accounting Research, 27, 153 - 192. http://dx.doi.org/10.2307/2491070

Mikhail, M., Walther, B., \& Willis, R. (2003). Reactions to Dividend Changes Conditional on Earnings Quality. Journal of accounting, auditing and finance, 18(1), 121-151. http://dx.doi.org/10.2139/ssrn.170559

Penman, S. H., \& Zhang, X. (1999). Accounting Conservatism, the Quality of Earnings, and Stock Returns. The Accounting Review, 77(2), 237-264. http://dx.doi.org/10.2139/ssrn.201048

Pratt, J. (2000). Financial Accounting in an Economic Context (4th ed.). Cincinnati, OH: South-Western College Publishing.

Rayburn, J. (1986). The association of operating Cash Flow and Accruals with Security Returns. Journal of Accounting Research, 24, 112-133. http://dx.doi.org/10.2307/2490732

Revsine, L., Collins, D., \& Johnson, B. (1999). Financial reporting and analysis (1st ed.). New Jersey: Prentice Hall, Upper Saddle River.

Richardson, S. A., Sloan, R. G., Soliman, M. T., \& Tuna, I. (2001). Information in Accruals about the Quality of Earnings. Working Paper, University of Michigan Business School.

Richardson, S. A., Sloan, R. G., Soliman, M. T., \& Tuna, I. (2005). Accrual Reliability, Earnings Persistence and Stock Prices. Journal of Accounting and Economics, 39, 437-485. http://dx.doi.org/ 10.1016/j.jacceco.2005.04.005

Shroff, P. (2002). The Relation between Aggregate Earnings and Security Return over Long Intervals. Contemporary Accounting Research, 19, 147-164. http://dx.doi.org/10.1506/MX3L-QM8G-H7D8-FE17

White, G., Sondhi, A., \& Fried, D. (2003). The Analysis and Use of Financial Statements ( ${ }^{\text {rd }}{ }^{\text {ed.). UK: John Wiley }}$ and Sons.

Wilson, P. (1986). The Relative Information Content of Accruals and Cash flows: Combined Evidence at the Earnings Announcement and Annual Report Release Date. Journal of Accounting Research, 24, 165-200. http://dx.doi.org/10.2307/2490736 